\title{
The Structure of the Functional-Semantic Microfield of the Diminutiveness in Russian, German, Mari and Chuvash Languages
}

\author{
Natalia N. Kanashina \\ Mari State University, Yoshkar-Ola, Russia \\ Email: inter_office@marsu.ru
}

\section{Doi:10.5901/mjss.2015.v6n3s7p199}

\begin{abstract}
The article investigates the structure of the functional-semantic field of the diminutiveness in Russian, German, Mari and Chuvash languages. The author analyzes and compares the composition of the constituents in several microfields, determines the degree of congruence and differences in the languages of different systems.
\end{abstract}

Keywords: diminutiveness, diminutive, the functional-semantic field, microfield

\section{Introduction}

The field method of language description successfully used for more than half a century, combined with the theory of the nomination allows us to analyze the expression plane of the category of diminutiveness in modern Russian, German, Mari and Chuvash languages in detail, avoiding a narrow understanding of this category.

While determining the size of any object, we describe it in respect of its length, width, height, depth, etc. And if in the exact sciences the definition of the linear parameters is directly related to the calculation, the language has its own measurement system, which also "take into account" a form of the object and its position in the space. This valuation of the object's parameters is not absolute, it focuses on the standard of a number of such objects (Rakhilina, 2008). The concept of a parametric norm and a deviations from the norm is based on a standard, and may be situational. At least most of the native speakers evaluate the size of the object, based on their usual standards, functions and procedures of its use (Rakhilina, 2008).

The traditional understanding of the diminutive semantics is a reduced copy of the object, which changed all its linear parameter at the same time. This phenomenon, however, is rare, as it was confirmed by many studies. Diminutiveness as a parametric description of any object indicate not only a deviation from the norm (decrease), but also a change of one or more parameters, leading to the perception of this object as all reduced.

Quantitative descriptor, which performs a centralizing function, contains a number of distinctive features. According to features it is possible to mark several microfields in the structure of the functional-semantic macrofield of diminutiveness. The following microfields were identified:

- The microfield of dimensional diminutiveness,

- The microfield of quantitative diminutiveness,

- The microfield of attenuation,

- The microfield of immaturity,

- $\quad$ The microfield of local-temporal diminutiveness.

\section{Main Results}

\subsection{The microfield of dimensional diminutiveness.}

Based on the mental category of diminutiveness we understand under dimensional diminutiveness the representation of a reduced object as a whole or of an object with one or more reduced linear parameters. Research has shown that the core zone of the microfield of dimensional diminutiveness is constituted primarily by the diminutive derivatives, as well as by the lexical items with its own diminutive semantics.

Russian language has rich opportunities to derivate the diminutives by adding of diminutive postfix formant. The study has marked more than 30 models of derivation by adding of diminutive postfix formant, among them - 13 suffix- 
models of derivation of masculine diminutive nouns (the most frequent are -ок (-ёк) (погребок, паренёк), -ек (орешек, камешек), -ик (глазик, гвоздик); 13 suffix-models of derivation of feminine diminutive nouns (the most frequent are -к-a (квартирка, лесенка), -очк-а (-ечк-а) (вазочка, звездочка); 8 suffix-models of derivation of neuter diminutive nouns -ко (озерко, ведерко), -ц-е (-ц-о, -ец-о) (поленце, письмецо).

In German the derivation it is also considered to be a traditional way for formation of the diminutives, despite of the certain limitations of the diminutive formants as against of the Russian language. Thus, there are two main formant, which represent the small size: -chen (Häuschen) and -lein (Tischlein). Their dialectal variants are less frequent -gen, -sken, ske, -sche, -ilchen, -kin, -ke (e) n, -che, -tje (n), -tsje (n), -(e) li, -(e) le, -erl (e), -lin, -len, -la, -li (Kindergen, Stücksken, Messerle, Dirndl).

The core zone of the microfield of the dimensional diminutiveness in Chuvash language is also constituted by the diminutive derivates: -ак (-ек, -ах) (с̧ытак), -ӑк (-е̌к, -к) (ке̌nе̌к), -ска (-ске) (тӗмеске), -шка (-шке) (сунашка), - шкӑ (шкӗ) (пӑрушкӑ), -с̧ӑ (с̧ӗ) (пиччес̧е̌м), -ча (-че) (йӑвача),-чӑк (-чӗк)( пӗрче̌к (Andreev, 1985). However, the derivation in the Chuvash language does not play a major role in the formation of diminutives.

Mari language does not show any diminutive derivation models. There are only a few lexical items with diminutive suffix borrowed from the Russian language, that does not allow to single out the formant method as a direct diminutive nomination in the Mari language.

The role of the prefixal morphemes in the formation of diminutiveness is inconspicuous, so diminutive derivatives formed with prefixal morphemes belongs to the circumnuclear part of the microfield. General diminutive prefixes in German and Russian languages (borrowed) are мини- (mini-) and микро- (mikro-): мини-юбка, микросистема(in Russian) and Minikleid, Mikroaufnahme (in German).

Along with the derivation of the diminutives the stem-composition has a similar formal meaning in German. An independent stem with the objective diminutive semantics serves as a rule as a diminutive component of the composite. The most frequent composites, which are the first stems of adjectives, are klein, kurz, dunn, eng, minimal, minder (Kleinstadt, Kurzwelle). The first substantive component are components as Teil-, Miniatur-: Teilstrecke, Miniaturausgabe.

The attributive word combinations (AdjDim + Nom) with parametric adjectives which contains a reference to the small size are also very important constituents of the microfield of the dimensional diminutiveness, for example: in Russian -малый, маленький, небольшой, крохотный, мизерный; in German - klein, gering, nicht groß, nicht groß genug,winzig, in Chuvash - пӗчӗк, вӗтӗ (вӗт), пысӑкмар, пысӑкӑх; in Mari - изи, кызыра, тыгыде, пырче-парче (Марла мутер, electronic dictionary).

The circumnuclear part of the microfield is constituted by the phraseological units with the quantitative diminutive meaning. Thus the basic standard for measuring and comparing of the objects can be body parts of a human or animals, or minor functional items used by humans in everyday life. In Russian, we find the following diminutives: $c$ ноготок, $C$ волосок, с мизинец, с гулькин нос, с наперсток; in German -kleinfingerbreit, klitzeklein; in the Mari language - кӱч наре, име нер гай; in the Chuvash - пӱрнеске пекскер.

Finally, the periphery zone of the above mentioned microfield is constituted by the diminutives with the metaphoric quantitative meaning, such as поросячьи глазки, Finkennäpfchen. In this case, the quantitative value is structurally conditioned, and requires certain factors to be implemented.

\subsection{The microfield of quantitative diminutiveness.}

The language units that implement the invariant meaning of a small number, are not heterogeneous and include explicative and implicative forms. The core zone of the microfield of quantitative diminutiveness is constituted by the explicative forms. In the analyzed languages the quantitative descriptor is directly represented by universal quantifiers. The quantifier "few", "a small amount" exists in any natural language. The construction "Quant + Nom" is as a rule a common form of its implementation. The most frequent quantifiers which determine the quantitative characteristics of some individual items or groups in Russian are мало (маленько), немного (немножко, немножечко), небольшое (малое) количество, минимум, мелочь, малость, чуть, всего ничего, всего-навсего, всего только/всего лишь; in German - ein bißchen, das bißchen, ein klein bißchen, etwas, nicht viel, wenig, nicht zahlreich, gering, eine Kleinigkeit; in Mari - шагал, шагалын, изиш(ак), изин-изин, иклаштык, икмыняр, пырт, пычырик, чуч; in Cuvash - кӑшт, кӑщт-кашт, кӑштах, кӑшт кӑна, сахал, пӑртак, пули-пулми,пӑртаккӑ, тепӑртак.

The following nominative units express also a deep diminutive semantics, they determine small, discrete groups, for example группка, кучка in Russian; Grüppchen, Häufchen in German; пучка, сарым in Mari; ушкӑн, купа, с̧ыхӑ in Chuvash.

The mesuratives are used for a quantitative specification of non-discrete groups, they point to a small amount of 
substance or a small measure. As mesuratives the conventional and unconventional units can be used. The Russian language has genitive-partitive construction with "dimensional" components as грамм, гран, дюйм, йота, унция, вершок (уст.), пядь, (уст.), золотник (уст.); in German - Gram, Gran, Lot, Jota, Unze, Zoll, Quentchen (ycm), Spanne (yсm); in Mari - грамм, дюйм, вершок, шеч; in Chuvash - с̧ур пус, шит, шит тӑршшӗ.

At the same time, the language with ist anthropocentrism has the lexical units, which represent the human body as a standard of measure, such as in Russian language - зуб (на один зуб, на зубок), мизинец (на мизинец, с мизинец), ноготь (с ноготок), горсть; in German - Hand (Handvoll), Daumen, Finger (Fingerbreit), Fuß (Fußbreit), Nagel (Nagelbreit); in Mari -кормыж, чывыштыш, чывышталтыш, кынер; in Chuvash -ьвӑс̧ (хӑрах ывӑс̧), качапу̃рне (кача пӱрне пысӑкӑш), печчӗк чӗрне, чӗрне хури чухлӗ. The unconventional units can also be used as explication means of a small amount, for example in Russian -ложка (в час по чайной ложке), наперсток, шкалик; in German Fingerhut, Löffel, Messerspitze; in Mari - совла; in Cuvash - кус̧тушкӑ, пӱрнеске.

The periphery zone of the above mentioned microfield is constituted by the diminutive partitives, for example in Russian доза, доля, порция, часть, кусок, осколок, обломок, остаток; in German - Anteil, Teil, Dosis, Portion, Stück, Brüchling, Rest; in Mari - ужаш, пай, пудырго, комыля, катыш, катык, ластык, кандар, пытартыш; in Chuvash - касӑк, татӑк, тӗпренчӗк ванчӑк, хйс̧ӑк, юлашки. The direct nomination of a small amount through the structure "Npart + Nom", however, is possible as a rule only in the presence of diminutive adjective.

The following partitatives can also show the deep semantic of a small amount: in Russian - лепта, толика, частица (частичка), капля, кроха, глоток, огрызок; in German - Schluck, Tropfen, Bissen; in Mari - увыра, пырчьк, пултыш, чӱчалтыш; in Chuvash - тумлам, тумла (тумла шывӗ), вакланчӑк, ванчӑк, сыпкӑм, хӗлхем, пӗрчӗ.

The diminutive numeratives also constituate the periphery zone of the microfield of quantitative diminutiveness. But only constriction "Num + Nom", which is not related to the exact number, can be considered as a part of the above mentioned microfield. This construction represent as usual the undetermined small amount, for example in Russian $\partial в а$ (в два счета, с двух словах, в двух шагах), раз-два (раз-два и обчелся), один-два, два-три, три-четыре в свободных словосочетаниях один-два раза, два-три случая, три-четыре просмотра; in German - ein-zwei, zweidrei, drei bis vier, zwei-drei Male, drei-vier Tage; in Mari - ик-кок, ик-кок гана, ик чйчалтыш гына, ик чйчалтьшат уке, кок пачаш, кок гана, кок мут дене; in Chuvash - пӗр-ик, пӗр (пӗр самантрах, пӗрре-иккӗ с̧ех).

The peripheral segment of microfield specific to each language, is constituted by the phraseological units, which quantify the small number, for example in Russian - кот наплакал, капля в море, рожки да ножки, не стоить и мизинца, смотреть не на что, не бог весть сколько, по пальцам пересчитать, с гулькин/воробьиный нос; in German - ein Tropfen im Meer, ein Tropfen auf einen heißen Stein, ein trauriger Rest, nur ein Nasenwasser sein, sehr schwer zu finden sein; in Mari - парня ута, тенъызысе чӱчалтыш вӥд, умшам нӧрташ веле; in Chuvash - тинӗсри шыв тумламӗ пек, пӑхмалӑх та с̧ук, пӗр алӑри пӳрнесемпе шутласа тухма пулать.

\subsection{The microfield of attenuation.}

If we try to analyze the intensity in terms of diminutiveness, we explore the attenuation of any feature or process; the movement on a scale of intensity in the direction of their weakening.

The Russian language has several derivational formants, which give to adjectival derivatives formed with their help the semantics of weakening, there are such formants as: -оват, -еват (черноватьй, слабоватьй), -оньк, -еньк (бледненький, свеженький), -ощав (сухощавый, худощавый). The adverb formants have the same function: -енечко (легонечко), -овато, (-евато) (бедновато).

In German the formant -lich, along with several possible meanings, finds out the diminutive semantics in special distribution conditions and may give to the adjectives the meaning of low intensity such as: gelblich, wärmlich. Suffix-arm: blutartm, fischarm probably does not point to incompleteness of feature, but to a small number of entities, called by the generating stem.

Following adjectival formants implement the diminutive semantics in Mari language: -алге (-ялге) (лудалге, нарынчалге) and -ma (щучката, лапката).

The Chuvash formant -pax (-pex) can be compared with the Russian -оваm, -еваm and gives to adjectives the meaning of incompleteness, "lack of quality ". In addition, the Chuvash language has several other formants, which are used to derivate the diminutive form of adjectives, for example: -çӗ, -çес̧çӗ: пӗчӗкçӗ; -ка(-ке, -кке) (имшеркке, мӑнтӑркка); -ак(-ек) (тӑварлак, шывак; -шка(-шке): ланчашка, лутрашка).

As it was considered, the core zone of the microfield of attenuation is constituted by the adjective derivatives with diminutive formant in the studied languages.

The descriptor "low intensity" in verbal action also can be expressed in different levels of language means. In the 
Russian language the attenuative verbs should be mentioned in the first place, the diminutive semantics is implemented by the following formats: nо-, nод-, при-, вс- (вз-) (поразмяться, подкопать, прикрыть, всплакнуть). Semantics of the weak intensity of action can be also implemented by the formants: недо-, полу- (недоедать, полуотворять).

In German, there are also suffix-formants, which express the semantics of weakening - (e) In, - (e) $r n$ and prefixformant an-, nach-, dazu- (hüsteln, kränkeln, anheben, antrinken, nachfärben).

It should be mentioned that all the studied languages have a small group of verbs with implicit seme of weakening action, such as in Russian: моросить, просачиваться, капать, накрапьвать etc.; in German: lüften, lüpfen, schwindeln, dösen, schimmern; in Mari: чарналташ, чырыпланаш, шыжаш, пелемдаш, маралташ; in Chuvash вӗтӗртет, тумлат, шӗnӗртет, пӑчлат.

The lexical deintensifiers can be pointed out as a separate functional class of language means, which indicate the attenuation in feature and procedural semantics. The most frequently used adverbial deintensifiers in Russian are eдвa, едва-едва, еле, еле-еле, немного, чуть, чуть-чуть, чуточку, несколько, слегка, в некоторой степени; in German ein bißchen, ein klein bißchen, etwas, ein wenig, ein klein wenig, nicht genug, kaum; in Mari - изин, изиракын, изишизиш, изиш(ак), икмыняр, ныжык-ныжыкые, пеле-пеле, пыкше, пыкше-пыкше, кырт, тока, чак-чак, тиок(ат), чуч, теве-теве, исак; in Chuvash - аран, ерипен(н), пӗчӗккӗн, майӗпен, майӗпеле, кӑшт, кӑштах, кӑштӑн, кӑштӑн-кӑштӑн, кӑшт-кӑшт, кӑштӑ, кӗлт-пӗртек, ке̌ç- кӗс̧, пӑртаккӑ, пӑртаккӑн, пӑртакс̧ӗ, пӑртиккех, пӑштӑн, пӗчӗккӗн, пӗчӗксӗн, сахаллӑн, сахалшар, чутах. These lexical units are characterized by the usage in analytical structures as a determinant of both adjective and verb. Thus the studyhas pointed to some similarities in analytical models " deintensifiers + adektiv (or verb)" in the studied languages (Kanashina, 2012).

\subsection{The microfield of immaturity}

The expression of small age, in other words the designation of immature beings can be also considered as a part of the unktsional-semantic field of diminutiveness. The microfield of the immaturity is represented in the studed languages by the constituents of different language levels.

As the most common way to define the immature beings in the Russian language are the following formants (-ёнок) (волчонок, оленёнок), -оныш (-ёныш) (гусёныш, зверёныш), -ыш (крепыш, приёмыш), -ат (-ят) (дошколята, котята, орлята). The following formants are used a bit rarely: -ик (братик, котик), -ишк (братишка), -к (барашек), -ец (агнец, братец), -ок (-ек) (бьчок, внучок), -оньк (-еньк) (внученька), -очк (белочка), -чик (жеребчик). For the second group of derivatives the parametric adjective indicating the young age can be used.

In contrast to the Russian language there is no suffixes of immaturity in the German language, thus the lexical units play a significant role in the nominating of children and young animals, they onstitute the core zone oft he above mentioned microfield: Kind, Junge, Jungtier, Tierjunge, Welpe, Ferkel, Kücken, Kalb, Fohlen; and substantivization (der, die, das) Kleine, (der, die) Jugendliche. German diminutive suffixes -chen and -lein, however, can also have the meaning of immaturity: Kindchen, Mädchen. But in this case the additional parametric adjectives are required to refer to the small age.

In the Chuvash and Mari the second component as çypu, чěnnu (in Chuvash) и uгe (in Mari) are used to nominate the young animals and chicks: in Chuvash - сыснӑ с̧ури, кӑвакал чӗnn; in Mari - маскаиге, пuрuгe.

Russian language also has a significant amount of lexical units with their own meaning of "childishness", especially common are the stem morphemes as -дев-, -дет-, -мал-, -реб-: дева, девочка, детва, детка, дети, детвора, мальчик, мальш, мальшка, мальшня, мальчуган, малютка, малявка, ребенок, ребята, ребятишки. The following lexical items are not rare: дитя, дитятко, карапуз, грудничок, сосунок, сопляк; similarly in Mari аза, изиен, рвезе, икшыве, тетя, йоча, ньога, шочшо; in Chuvash - ача, ача-пӑча, пепке, пӑран, путек, хӗр, хӗр ача, яшкӗрем, пӑру, пӑшu пӑрушӗ, muxa, çăвӑр.

As noted above, the parametric adjectives play the determining role in the designation of young beings: in Russian - мальй, маленький, молодой, невзросльй, небольшой; in German - klein, jung, jugendlich, halbwüchsig; in Mari изи, мызыри, пыйыртки, самырык, ныжмык, ужарвуян and in Chuvash - пӗче̌к, с̧амрӑк, ке̌с̧ӗн, яш.

The periphery zone of the microfield of immaturity is constituted by the phraseological units, for example in Russian om горшка два вершка, молоко на губах не обсохло, совсем зеленый, мал мала меньше, желторотьй nтенец (in Russian); noch sehr grün sein, kaum drei Käse hoch sein, nochfeucht / grün / nicht trocken hinter den Ohrensein, noch die Eier schalen hinter den Ohren haben, noch ein halbes Kind sein (in German); качă пурне пысӑкӑш çес̧, сарӑ тута, пӗринчен тепри пӗчӗккӗ, тута [cӗm, чӗчӗ] сари кайман (in Chuvash); ава чызе гыч (деч) ойырлен огыл, тӱрвыштӧ (чызе, ава) шӧр кошкен шуын огыл, ужарвуй (in Mari).

In addition to the objective characteristics (in this case the designation of small age and the associated 
metaphorical transfer to the small size), the idea of diminutive includes a subjective attitude of the speaker to the designated object. This range of emotions is truly rich and includes all shades of feeling from the positive (affection towards the child or young animals) to contrast the negative (rejection and contempt of immaturity). This is why the language has a huge number of metaphorical expressions of negative assessment in relation to an adult person who has certain qualities of the child.

\subsection{The microfield of local-temporal diminutiveness}

The dyad "space-time" according to the Einstein's theory of relativity appears as a single form of existence. Ontologically space and time are inseparable. The space is four-dimensional, that is, the position of any event is defined by four coordinates, three spatial and one temporal (Stepanov, 1985). Since temporality as a physical quantity, defined as the length of time, the temporal characteristic of the object is considered to be similar to its deployment in space.

Discovering the world at the elementary level, we perceive the space and time as its absolute characteristics. Realizing itself in the space-time continuum, the person interprets the visual information and implement the space in natural language in its standard- common understanding outside of its philosophical and scientific context (Kobozeva, 200). The time information is similarly analyzed and verbalized. Thus, the basic spatial and temporal relationships can be implement in the language in forms with a single existential functionality that allows us to isolate the common area in the functional-semantic microfield of local-temporal diminutiveness.

The temporality and locality have a clear deictic description. Deictic center can be anthropocentric and be the same as the moment of speech and the location of the speaker, but can also have a an external object as a center.

The core constituents of the studied microfield are characterized by an equal usage in the determination of objects and actions from the point of their location of time. Direct spatial and temporal proximity is implemented by the following explicative forms, in Russian - близость, близкий, ближний, близко, недалекость, недалекий, недалеко, недолгий, недолго, короткий, накоротке, небольшой (небольшой отрезок, небольшой промежуток времени), немного, сразу; in German - die Nähe, in der Nähe, in unmittelbarer Nähe, in nächster Nähe, in aller nächster Nähe, nah(e), kurz, dicht an; in Mari - лишыллык, лишыл, лишылын, чак, лишан, кӱчык, изи, изиш, тураште; in Chuvash с̧ывӑх,с̧ывӑхрах, с̧ып-с̧ывӑх,с̧ывӑхран, с̧ывӑхра (вӑл с̧ывӑх рахпурӑнать), с̧ывӑхран, с̧ывӑхри, инс̧емар, кӗске, кӗскен, нумаймар.

The nomination of small distance of the object in space is implemented by the direct locative, for example, in Russian близь, близ, вблизи, поблизости, близлежащий, недальний, недалеко, невдалеке, невдали, неподалеку, недалече, возле, подле, около, рядом, на небольшом расстоянии, соседний, смежный, по соседству, в районе, в виду, вплотную, в упор, в нескольких шагах, рукой подать, на подступах, на подходе; in German - eine geringe Entfernung, naheliegend, nahe stehend, in der näheren Umgebung liegend, nahebei, unweit, unfern, nicht weit entfernt, am wenigsten weit entfernt, neben, nebenan, nebenbei, anliegend, angrenzend, benachbart, in der Nachbarschaft; in Mari - лиш(ке), пелен, воктелан, воктене, воктенысе, пелен, изиш ӧрдыжтырак, кӱдынь, кӱдык(ӧ), йыгыре, тембалне, тембач(ын); умбакпыштет, тембачналат), лишыч(ын), тембалан, тембак(е) (тембактолаш), тембалсе, лишылсе, воктек(е), шырке; in Chuvash - патра, аяккинче, аякрамар, патӗнче, сумӗнче, юнашар, с̧ывӑхёнче, с̧умра, сууммӑн.

However, while determining the immediate local characteristics of the object these locatives can also point to the temporal components of the semantics, namely the quickness of overcoming the short distance to the object. A similar characteristic of the distance in terms of time give, for example, the following temporatives: в пяти (десяти) минутах ходьбы, в минуте ходьбы in Russian, einige Minuten zu Fuß in German, кунтан пилӗк минут утмалӑх in Chuvash.

A small time interval, or the action or phenomenon, occurring in a short period of time can be explicated by the following lexical units: мгновение, мгновенно, миг, мигом, момент, моментально, моментальный, моментальность, секунда, секундный, минута, минутка, пятиминутка, минутный, в одночасье, краткий, непродолжительный, кратковременный, быстрый, по-быстрому; in German - eine Weile, ein Weilchen, eine Sekunde, in Sekundenschnelle, Augenblick, augenblicklich, Moment, momentan, im Nu, jäh, blitzschnell, pfeilschnell, schlagartig, mit einem Mal; in Mari - тат (иктатлан), икжаплан, пагыт, пыртлан, изишлан, вашке, содор, вашкен, вигак; in Chuvash - пӗравӑк, самант, самантрах, пӗрсамантра, кӗскевӑхӑт, (пӗр) сехет, ŭănăpmлăx(a),ŭănăpm, numсахалвӑхăm, наччас, наччаслӑх, наччасра, ал-хапӑл, васкаварлӑн (Kanashina, 2013).

The parts of the human body (of animal in rare cases) can serve as a local and temporal determiner. For example, in Russian: над ухом, под боком, под рукой, под носом, на хвосте, за, не успеешь глазом моргнуть, не успеешь обернуться;in German - zur Hand haben, handgerecht, hautnah, im Handumdrehen, also Hörweite, Sichtweite, greifbar, in Grffnähe, in greifbarer Nähe; in Mari - йолйымалне, шинчаваш, нермучаште; in Chuvash -сӑмсаайӗнчех, 
кус̧ хупсаиличчен, пӗркус̧ хупӑмнӗче, алтӑсмалӑх с̧ес̧. The natural objects and home units can also mark the temporal and spatial dislocation, in Russian - не за морем, не за морями, не за горами, у порога; in German - vor der Tür stehen, an der Schwelle (an der Schwelle des Greisenalters), in Chuvash - maçma uнçe мap (Kanashina, 2013).

\section{Conclusion}

The analysis of the microfields of the functional-semantic field of diminutiveness allows us to draw a conclusion about their relative congruence in Russian, German, Mari and Chuvash languages, which is based on the logical perception and explication of the relevant quantitative determination of small objects. However, microfields in the studied languages show some specificity verbalization of conceptual category of diminutiveness, which is reflected in the structure of the common functional-semantic field of diminutiveness.

\section{References}

Rakhilina, E.V. (2008). The cognitive analysis of subject names: semantics and compatibility. Moscow, p.118.

Andreev, A.I. (1985). Chuvash-Russian Dictionary. Moscow

Марла мутер. The electronic dictionary of Mari language. [http://marlamuter.com/]/

Kanashina, N.N. (2012). Attenuation as a component of the functional-semantic field of diminutiveness in Russian, German, Mari and Chuvash languages.// Vestnik of Chuvash State University. Cheboksary, № 2, p. 280.

Stepanov, J.S. (1985). In three-dimensional space of the language. Moscow, p. 125.

Kobozeva, I.M. (2000). Grammar of the space description. Logical analysis of language. Languages of spaces. Moscow, p. 154.

Kanashina, N.N. (2013). Microfield of the local-temporal diminutiveness as part of the functional-semantic field of diminutiveness. XXI century: Resumes of the Past and Challenges of the Present plus. Penza, № 8, p.193. 